\title{
UPAYA PENINGKATAN KUALITAS PELAYANAN PADA UMM MEDICAL CENTER MALANG
}

\author{
Ahmad Faris Royhan \\ Department of Management FEB UMM \\ E-mail: ahmadfariz94@gmail.com
}

\begin{abstract}
The purpose of the study was to examine service quality, service attribute, and technical response that should be prioritized based on House of Quality design in Medical Center UMM. This study applied Quality Function Deployment method. The results of the study showed that technical response and service attribute should be developed again. The important aspect of technical response was communication and behavior ethics of staffs. They could make 11 technical responses as strategies to improve service quality in Medical Center UMM.
\end{abstract}

Keywords: house of quality, improved quality of service, quality function deployment

\section{PENDAHULUAN}

Perkembangan dunia usaha pada sektor jasa saat ini telah memperlihatkan kemajuan yang sangat pesat. Hal ini terjadi seiring dengan perkembangan teknologi, ilmu pengetahuan dan informasi yang selalu mengalami perubahan. Pengembangan produk adalah suatu keharusan bagi perusahaan apabila tetap ingin bersaing. Pengembangan produk biasanya memerlukan proses yang panjang karena akan dilakukan banyak tahapan serta setiap tahapan akan saling terkait serta ditunjang oleh organisasi perusahaan yang efektif.

Pengembangan produk dilakukan agar pelanggan tidak jenuh dengan produk awal, dan berdampak kepada penurunan penjulan. Salah satu cara mengembangkan produk yaitu menambah layanan. Layanan yang ditambahkan akan melengkapi produk inti sehingga penilaian konsumen pada produk inti akan semakin baik yang dengan mengalihbahasakan hal yang konsumen inginkan. Perusahaan yang akan melakukan pengembangan produk harus mengetahui kebutuhan dan keinginan konsumen.

Salah satu metode yang bertujuan mengembangkan kualitas untuk memenuhi hal yang konsumen inginkan menjadi target desain yaitu QFD. QFD (Quality Function Deployment) yaitu merupakan metode yang menjamin kualitas pada setiap tahap proses pengembangan produk, dimulai dengan desain kualitas itu sendiri.Model ini merubah apa yang diinginkan konsumen menjadi karakteristik kualitas dan mengembangkan perencanaan kualitas untuk mendapatkan hasil akhir yang memuaskan. 
Industri jasa erat kaitannya dengan kepuasan konsumen sehingga perlu menjadi perhatian utama konsumen. Perusahaan yang baik adalah perusahaan yang mengerti prioritas, untuk perusahaan jasa maka kepuasan konsumen yang perlu diperhatikan. Kepuasan konsumen akan terpenuhi saat kebutuhan dan keinginannya terpenuhi, jika tidak terpenuhi maka konsumen bisa saja tidak menggunakan jasa perusahaan kembali. Dampak yang akan dirasakan langsung oleh perusahaan saat konsumen tidak puas adalah konsumen akan berkurang.

Mencegah dampak langsung dari kurangnya kepuasan konsumen maka perusahaan dapat menggunakan metode Quality Function Deployment (QFD). Metode QFD digunakan untuk mencari permasalahan terhadap apa yang sebenarnya paling diinginkan dan diharapkan oleh konsumen. QFD juga dapat diaplikasikan untuk pegembangan produk jasa salah satunya produk jasa kesehatan. Metode QFD akan membantu memecahakan masalah dengan menentukan hal yang konsumen inginkan dan butuhkan yang akan diterapkan pada produk maupun jasa. Industri jasa yang terus berkembang dan banyak menuai kritikan adalah industri jasa di sektor kesehatan, sehingga sektor ini perlu melakukan perbaiakan terus menerus.

Kesehatan merupakan sesuatu yang sangat berharga bagi setiap orang, sehingga mutlak harus dijaga oleh setiap orang dengan sangat baik. Sehat merupakan kondisi optimal fisik, mental, dan sosial seseorang sehingga dapat memiliki produktivitas. Meningkatkan derajat kesehatan masyarakat banyak hal yang perlu dilakukan, salah satu diantaranya dengan menyelenggarakan pelayanan kesehatan. Metode qfd akan membantu memecahakan masalah dengan menentukan hal yang konsumen inginkan dan butuhkan yang akan diterapkan pada produk maupun jasa. Industri jasa yang terus berkembang dan banyak menuai kritikan adalah industri jasa di sektor kesehatan, sehingga sektor ini perlu melakukan perbaikan terus menerus.

UMM Medical Center adalah usaha dibidang jasa kesehatan yang berada di Jl. Bendungan Sutami, Sumbersari, Kota Malang. Usaha ini adalah suatu pusat layanan kesehatan melayani berbagai macam layanan kesehatan secara lengkap dan terpadu. Pelanggan tidak perlu direpotkan untuk mendapatkan layanan kesehatan, secara terpisah atau berpindah-pindah dari satu tempat yang berkualitas. Tenaga medis dan paramedis yang berpengalaman serta kompeten dibidangnya.

Metode QFD terdapat langkah benchmarking yaitu membandingkan kinerja pada suatu aktifitas yang sejenis. Benchmarking biasa dilakukan membandingkan produk sendiri dengan produk pesaing. Membandingkan suatu produk dengan produk yang lebih baik atau yang setara yang menjadi tolok ukur. Tujuannya ialah untuk meningkatkan keunggulan kompetitif dengan menggunakan kinerja pesaing utama. Dengan begitu perusahaan akan dapat bersaing dengan para kompetitornya dalam dunia usaha. Pada penelitian ini, yang diangkat sebagai benchmarking ialah 
Poliklinik Universitas Brawijaya Malang.

Poliklinik Universitas Brawijaya Malang adalah poliklinik milik Universitas Brawijaya Malang, klinik yang beralamatkan di jalan Mayjen Haryono 163 berdiri sejak 2005. Poliklinik Universitas Brawijaya Malang digunakan sebagai benchmarking karena klinik ini telah lebih dulu ada dibandingkan dengan UMM Medical Center. Selain itu kedua klinik ini sejenis karena samasama milik universitas ternama di Malang.

UMM Medical Center memiliki website resmi, namun sekarang tidak pernah ada update data terbaru. UMM Medical Center tidak memiliki alat kesehatan yang lengkap, hanya alat USG yang tersedia. Saat ini UMM Medical Center tidak melakukan promosi, hal tersebut yang membuat klinik ini menjadi tidak dikenal. Klinik ini hanya dikenal oleh para internal Universitas Muhammadiyah Malang, masyarakat umum cenderung enggan untuk berobat di UMM Medical Center.

Berdasar uraian pada latar belakang dapat diketahui bahwa peningkatan kualitas produk serta kepuasan pelanggan merupakan permasalahan dari penelitian ini. Hal di atas memotivasi penulis mengambil judul "Upaya Peningkatan Kualitas Pelayanan pada UMM Medical Center". Tujuan dari penelitian ini adalah untuk mengetahui dan menganalisa layanan yang dibutuhkan dan diinginkan oleh pengunjung UMM Medical Center kemudian menganalisa atribut layanan apa yang diprioritaskan untuk ditingkatkan berdasarkan penilaian pengunjung dan apa yang harus diprioritaskan untuk meningkatkan kualitas layanan berdasarkan hasil penyusunan House of Quality di UMM Medical Center.

\section{TINJAUAN PUSTAKA}

Menurut (Philip Kotler, 2003) pengembangan produk menjadi konsep fisik dengan tujuan menyakinkan bahwa gagasan produk dapat diubah menjadi produk yang dapat bekerja. Pengembangan produk usaha yang direncanakan dan dilakukan secara sadar untuk memenuhi dan memperbaiki produk yang ada atau menambah banyaknya ragam produk yang dihasilkan dan dipasarkan, yang mana proses pengembangan produk itu sendiri biasanya dilakukan secara terus menerus, mulai dari produk apa yang dihasilkan perusahaan dan yang perlu diadakan, sampai kepada keputusan untuk menghasilkan suatu pruduk tertentu.

\begin{tabular}{llr}
\multicolumn{1}{c}{ Tingkatan } & produk & dapat \\
digunakan & sebagai & metode \\
pengembangan & produk. Mempelajari \\
tingkatan & produk & dapat
\end{tabular} merencanakan dan memprediksi produk potensial yang akan diproduksi. Merencanakan penawaran suatu produk, pemasar perlu memahami lima tingkatan produk yaitu: produk inti, produk generik, produk harapan, produk pelengkap, produk potensial (Philip Kotler : 2003).

Terdapat langkah-langkah untuk mengetahui sejauh mana tingkat kepuasan konsumen yang merupakan faktor penting untuk menjawab voice of customer (suara konsumen), sehingga didapatkan kemampuan untuk menjawab kebutuhan dari 
konsumen tersebut. Metode yang dapat digunakan untuk mengukur kepuasan pelanggan tersebut antara lain (Nasution, 2001).

Fokus utama dari QFD melibatkan pelanggan pada proses pengembangan produk sedini mungkin.

Filosofi yang

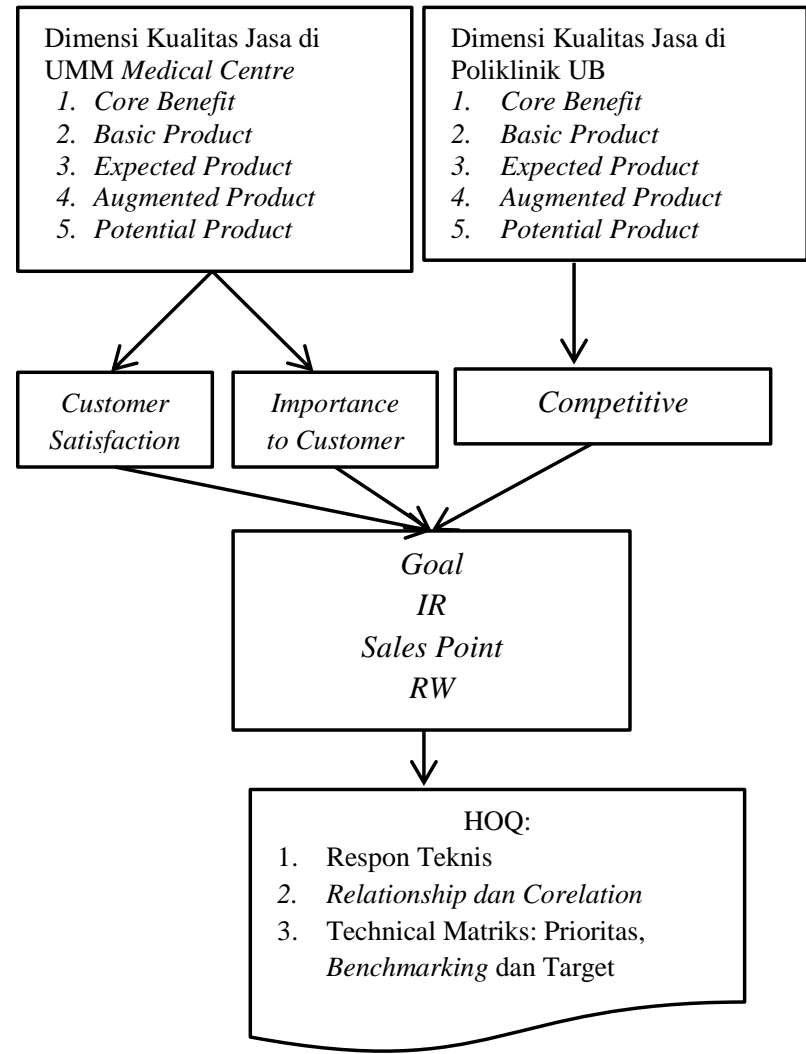

Gambar 1. Kerangka Pikir

Kerangka pikir merupakan cara yang digunakan untuk mempermudah alur pemikiran yang akan dilakukan dalam penelitian. Kerangka pikir penelitian ini ditunjukkan oleh Gambar 1 dan dapat disimpulkan bahwa, harapan pelanggan jasa dan kinerja perusahaan jasa berdasarkan lima dimensi tingkatan produk, yaitu core benefit product, expected product, augmented product, potential product. mendasarinya adalah bahwa pelanggan tidak akan puas dengan suatu produk meskipun produk itu telah dihasilkan dengan sempurna bila mereka tidak menginginkannya atau membutuhkannya (Nasution, 2006). Adapun kerangka pikir dalam penelitian ini yaitu:

Dimensi Kualitas Jasa di

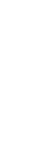


data yang dikuantitatifkan (Reksohadiprodjo, 2003).

Populasi (Sugiyono, 2010) adalah wilayah generalisasi yang terdiri dari obyek atau subyek yang menjadi kuantitas dan karakteristik tertentu yang ditetapkan oleh peneliti untuk di pelajari dan kemudian ditarik kesimpulannya. Populasi yang di gunakan dalam penelitian ini adalah seluruh masyarakat umum yang pernah menggunakan fasilitas pengobatan di UMM Medical Center, dan seluruh masyarakat umum yang pernah berobat di Poliklinik Universitas Brawijawa.

Sampel (Suharsimi Arikunto, 1998) adalah bagian dari populasi (sebagian atau wakil populasi yang diteliti). Sampel penelitian adalah sebagian populasi yang diambil sebagai sumber data dan dapat mewakili seluruh populasi. Dengan jumlah populasi yang besar, dengan keterbatasan waktu dan tenaga, maka jumlah sampel yang diambil sebanyak 30 responden, dengan rincian 30 responden diambil dari pengunjung UMM Medical Center dan 30 lagi dari pengunjung Poliklinik Universitas Brawijaya. Pertimbangan jumlah ini dianggap sudah memenuhi syarat menurut (Sugiyono, 2010) sampel yang layak dalam penelitian adalah antara 30 sampai 500 jumlah sampel. Dengan jumlah responden tersebut dianggap sudah mewakili untuk melakukan penelitian ini.

Tahap pengumpulan data suatu penelitian memerlukan proses data sampling. Penarikan sampel dalam penelitian ini menggunakan judgement sampling. Judmental sampling ditentukan kriteria tertentu untuk calon responden. Metode judgment sampling merupakan tipe pemilihan sampel secara tidak acak yang informasi menggunakan pertimbangan tertentu, yang umumnya disesuaikan dengan tujuan dan masalah penelitian.

Data primer yang akan digunakan adalah data kebutuhan pengunjung, data respon teknis dari pengunjung, serta data perbandingan dengan pesaing untuk membangun QFD dan HOQ. Data kebutuhan pengunjung didapat dengan memberikan kuesioner uji coba atau pertanyaaan terbuka kepada responden. Sedangkan data sekunder yang digunakan dalam penelitian ini antara lain gambaran umum perusahaan, sejarah singkat perusahaan, struktur organisasi perusahaan. Data sekunder dapat diperoleh dari buku, laporan perusahaan, dan lain-lain. Data yang dibutuhkan adalah data dari UMM Medical Center berkaitan dengan jumlah pengunjung dan data pasien UMM Medical Center.

Teknik pengumpulan penelitian ini menggunakan Mengajukan daftar pertanyaan secara langsung yang diberikan kepada responden tentang kualitas layanan yang ada di klinik. Wawancara Wawancara langsung dengan pasien klinik yang diteliti, sebagai pengguna jasa pelayanan untuk mendapatkan data tentang jasa pelayanan persepsi pasien. Wawancara ini juga dilakukan kepada pihak penyelenggara jasa pelayanan, yaitu dari pihak manajemen. Obeservasi dilakukan di UMM Medical Center untuk mengetahui kualitas pelayanan jasa rumah dari pengamatan peneliti.

Skala merupakan teknik pengumpulan data yang bersifat 
mengukur, karena diperoleh hasil ukur yang berbentuk angka-angka. Skala berbeda dengan tes, kalau tes ada jawaban salah atau benar, sedang skala tidak ada jawaban salah-benar, tetapi jawaban atau respon responden terletak dalam satu rentang (skala).

Teknik analisis data penelitian ini menggunakan beberapa metode yang melalui beberapa tahap yaitu:

Tahapan Pengumpulan Kebutuhan Konsumen (Voice of Custumer) Tahapan pengumpulan dan pengolahan data dengan konsep QFD adalah bagian dengan menganalisis data hasil kuisioner dengan mengidentifikasi keinginan dan kebutuhannya adalah tahap awal dari Quality Function Deployment (QFD).

Tahapan membuat matriks perencanaan (Planning Matrix) matriks perencanaan diperoleh melalui tanggapan yang dipentingkan pengguna atas pernyataan-pernyataan yang berkaitan perencanaan pengembangan pelayanan jasa. Tahapan terakhir menyusun House of Quality yaitu membuat rumah dari perhitungan di atas tadi. House of Quality berfungsi mempertemukan kebutuhan konsumen dan respon teknis.

\section{HASIL DAN PEMBAHASAN}

Pengumpulan data kebutuhan konsumen dalam penelitian ini dilakukan dengan mewawancarai 30 responden, 30 responden adalah pengunjung yang berobat di UMM Medical Center dan yang pernah mengunjungi UMM Medical Center. Pengumpulan data ini bertujuan untuk mengetahui atribut-atribut pelayanan yang baik dan kurang baik di UMM Medical Center yang selanjutnya dianalisa di tahap berikutnya.

Hasil dari wawancara diketahui 19 indikator yang sesuai dengan customer need yaitu: dokter profesional, pelayanan yang ramah, pelayanan pengobatan cepat, kebersihan ruangan, biaya pengobatan murah, bangunan luas, parkiran luas, fasilitas lengkap, lokasi strategis, diskon kepada pelanggan, kerjasama dengan asuransi, layanan 24 jam, pelayanan ugd, fasilitas apotek lengkap, ruang tunggu yang nyaman, promosi, kesigapan petugas, dokter spesialis fasilitas milik umm.

Tahapan Membuat Matriks PerencanaanBerdasarkan tingkat kepuasan konsumen, terdapat beberapan atribut yang berada di bawah 3, namun sebagian besar atribut berada di atas 3. Maka dianggap cukup memuaskan pengunjung UMM Medical Center. Sehingga hanya perlu melakukan beberapa perbaikan pelayanan, guna mendapatkan yang maksimal.

Atribut yang mendekati cukup adalah bangunan luas, fasilitas lengkap, dan pelayanan 24 jam. Sisanya adalah atribut yang dianggap cukup memuaskan pengunjung UMM Medical Center.

Tingkat kepuasan produk atau jasa pesaing merupakan tingkat kepuasan pengunjung terhadap Poliklinik Universitas Brawijaya Malang. Untuk menghitungnya sama dengan menghitung tingkat kepuasan pada UMM Medical Center, yaitu dengan membagi total nilai kepuasan dengan jumlah responden. Nilai ini akan digunakan untuk membandingkan kepuasan diantara 2 klinik yang nantinya akan 
memunculkan atribut-atribut yang harus dilakukan perbaikan dan atribut yang tidak perlu dilakukan perbaikan. atribut yang memerlukan perbaikan ada 12 item, sedangkan 7 item tetap karena dianggap baik oleh pelanggan di UMM Medical Center. 12 atribut yang memerlukan perbaikan adalah kebersihan ruangan, biaya pengobatan murah, bangunan luas, parkiran luas, faisilitas lengkap, diskon pada pelanggan, kerjasama dengan asuransi, pelayanan 24 jam, pelayanan UGD, ruang tunggu yang nyaman, promosi, dan dokter spesialis.

Atribut yang tetap dan tidak memerlukan perbaikan ada 7 item yaitu, dokter profesional, pelayanan ramah, pelayanan pengobatan cepat, lokasi strategis, fasilitas apotek lengkap, kesigapan petugas, dan fasilitas milik UMM.

Nilai rasio perbaikan yang harus dicapai oleh petugas dalam memperbaiki layanan rata-rata berada di atas 1, sedangkan yang berada di bawah 1 tidak dilakukan perbaikan. Semakin besar nilai, maka ateribut tersebut semakin perlu untuk mendapatkan dari pihak UMM Medical Center untuk segera dibenahi agar target mutu yang diharapkan dapat dicapai.

Tujuan dari penentuan titik kepuasan adalah untuk mengetahui seberapa besar manfaat penjualan yang mungkin diperoleh apabila perubahan-perubahan terhadap atribut tertentu. Menunjukkan tingkat penjualan suatu item di perusahaan kuat atau tidak. Titik kepuasan ditentukan oleh hasil wawancara dengan petugas sehingga memunculkan atribut-atribut yang memiliki nilai jual tinggi atau rendah. Bedasarkan hasil wawancara dengan petugas UMM Medical Center Malang tingkat titik kepuasan rata-rata adalah 1,5 dan 1,2 maka perlu dilakukan perbaikan.

Tahap Penyusunan Rumah Kualitas Respon teknis merupakan hasil penjabaran dari keinginan konsumen untuk menentukan target yang akan dicapai dan untuk menentukan atribut mana yang nanti akan dikembangkan.

\section{SIMPULAN}

Berdasarkan hasil penelitian dapat disimpulkan bahwa terdapat 19 indikator yang sesai dengan customer need. Berdasarkan perhitungan dan perbandingan dengan Poliklinik Universitas Brawijaya Malang, maka atribut yang harus ditingkatkan ada 12 atribut, sedangkan 7 item yang tidak perlu ditingkatkan adalah dokter profesional, pelayanan yang ramah, pelayanan cepat, lokasi strategis, fasilitas apotek lengkap, kesigapan petugas, dan fasilitas milik UMM.

Berdasarkan kesimpulan di atas, saran yang dapat diberikan adalah lebih memprioritaskan pelatihan komunikasi dan etika petugas, mempercepat pelayanan pengobatan, penambahan petugas kebersihan, penambahan fasilitas $\mathrm{AC}$, TV, dan WiFi, memberikan diskon pada pelanggan, menjalin kerjasama dengan asuransi, penambahan layanan 24 jam, penambahan layanan UGD, penambahan fasilitas apotek, memperbanyak promosi, dan pelatihan kesigapan petugas. UMM Medical Center dapat menjadikan 11 respon teknis sebagai strategi dalam 
melakukan perbaikan, sehingga dapat meningkatkan kualitas layanan di UMM Medical Center.

\section{DAFTAR PUSTAKA}

Arikunto, S. 2013. Prosedur Penelitian. Jakarta. Rineka Cipta.

Cohen, L. 1995. Quality Function Deployment : How To Make QFD Work For You. Addison Wesley: Publising Co.

Dale, Barrie G. 2003. Managing Quality. USA: Blackwell Publishing.

Heizer, Jay dan Barry Render. 2009. Operations ManagementManajemen Operasi. Edisi 9 Buku 1. Jakarta : Salemba Empat

Hurriyati, Ratih. 2010. Bauran Pemasaran dan Loyalitas Konsumen. Bandung: CV. Alfabeta, Bandung.

Husain, Umar. 2003. Metode Riset Bisnis. Jakarta : PT Gramedia Pustaka Utama

Kotler, Philip dan Keller.2012. Manajemen Pemasaran. Edisi kesebelas, Jakarta: Indeks kelompok Gramedia.
Nasution, M.N. 2010. Total Quality Management. Jakarta: Salemba Teknika

Purnomo, Hari. 2008. Pengantar Teknik Industri., Yogyakarta: Graha Ilmu.

Sanusi, Anwar. 2011. Metode Penelitian Bisnis. Jakarta: Salemba Empat

Sugiyono.2012. Metode Penelitian Kualitatif dan Kuantitatif dan R\&D.Bandung : Alfabeta

Sukadji, $\quad$ Soetarlinah. 2000. Menyusun dan Mengevaluasi Laporan Penelitian. Jakarta : UIPress

Sukanto, Reksohadiprodjo dan Indriyo.2008. Manajemen Produksi dan Operasi. Edisi keempat. BPFE-Yogyakarta.

Suryabrata, Sumadi.2004. Metodologi Penelitian. Jakarta: Raja Grafindo Persada

T, Yuri., Rahmat Nurcahyo. 2013. TQM Manajemen Kualitas Total Dalam Prespektif Teknik Industri. Jakarta: PT. Indeks

Zulganef. 2006. Pemodelan Persamaan Struktur dan Aplikasinya menggunakan AMOS 5. Bandung : Pustaka 